\title{
EROD activity and cytochrome P4501A induction in liver and gills of Senegal sole Solea senegalensis from a polluted Huelva Estuary (SW Spain)
}

\author{
Milagrosa Oliva ${ }^{\mathrm{a}, 1, *}$, Carlos Gravato ${ }^{\mathrm{b}, 1}$, Lucia Guilhermino ${ }^{\mathrm{b}, 1}$, \\ María Dolores Galindo-Riaño ${ }^{\mathrm{c}, 1}$, José Antonio Perales ${ }^{\mathrm{d}, 1}$ \\ a Department of Biology, Environmental and Marine Science Faculty, University of Cadiz, Puerto Real, Cadiz, Spain

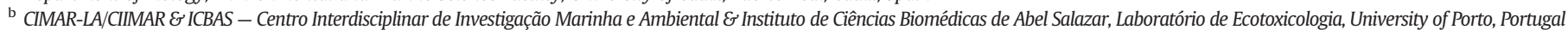 \\ c Department of Analytical Chemistry, Sciences Faculty, University of Cadiz, Puerto Real, Cadiz, Spain \\ d Department of Environmental Technologies, Faculty of Marine and Environmental Sciences, University of Cadiz, Puerto Real, Cadiz, Spain
}

\section{A R T I C L E I N F O}

\section{Article history:}

Received 8 May 2014

Received in revised form 28 July 2014

Accepted 30 July 2014

Available online 8 August 2014

\section{Keywords:}

Sole

CYP1A

EROD

Heavy metals

PAHs

\begin{abstract}
A B S T R A C T
EROD activity and induction cytochrome P4501A in liver and gills of Senegal sole, Solea senegalensis, from a heavy metal and PAH polluted estuary, was studied. Liver and gill CYP1A catalytic activity was assessed at the enzyme activity level-measured as 7-ethoxyresorufin-O-deethylase and cellular localization of CYP1A in the liver was studied using immunohistochemistry. Liver EROD was correlated with phenanthrene-type metabolites in liver and copper concentrations in water. Strong CYP1A occurrence was observed in acinar pancreatic cells, pancreatic duct epithelium and vascular system endothelium and negative/rare induction were observed in hepatocytes and sinusoidal endothelium. In gills, EROD activity showed a significant correlation with different fractions of heavy metals in sediment but no correlation was observed between EROD activity and PAHs. Strongly positive CYP1A associated staining of the vascular system endothelia and primary filament cells and a moderate staining of pillar cells in gills were observed. The results substantiated the utility of EROD activity and CYP1A induction measurement as biomarkers for use by aquatic toxicologists and indicate that catalytic assays and immunohistochemical assays appear to be sensitive to different kinds of pollutants being the use of both methods recommended for monitoring programs.
\end{abstract}

(c) 2014 Elsevier Inc. All rights reserved.

\section{Introduction}

Benthic fish from industrialized coastal regions are commonly exposed to long-term stress arising from exposure to sublethal contaminant concentrations. The application of cellular and molecular biomarkers in ecotoxicology depends upon basic information on xenobiotic biotransformation mechanisms.

Cytochrome P450s (CYP) comprises a superfamily of related hemoproteins that, in conjunction with several other enzymes, serve as an electron transport system to catalyze a multitude of monooxygenase reactions. The cytochrome P450 system is responsible for the metabolism of a wide range of endogenous and xenobiotic compounds. It is involved in the transformation of steroids, prostaglandins, fatty acids, and other

\footnotetext{
* Corresponding author at: Department of Biology, Marine and Environmental Science Faculty, University of Cádiz, Avda. República Saharaui S/N Puerto Real 11510, Cádiz, Spain. Tel.: + 34 956016016; fax: + 34956016019.

E-mail address: milagrosa.oliva@uca.es (M. Oliva).

1 These authors contributed equally to the study.
}

biological molecules. The CYP system also plays important roles in the toxicology, metabolism, and excretion of pollutants, drugs, and many carcinogenic chemicals and mediates the transformation of certain xenobiotics to their reactive intermediates.

In studies carried out in fish species, CYP1A seem to be a very sensitive biomarker of exposure to organic and inorganic pollutants, which will certainly be feasible in environmental risk assessment (ERA) procedures. CYP1A determinations may be used in various steps of the ERA process, such as quantification of impact and exposure of pollutants, environmental monitoring of organism and ecosystem 'health', identifying subtle early toxic effects, triggering of regulatory action, identification of exposure to specific compounds, toxicological screening and research on toxic mechanisms of xenobiotics. The CYP1A response has been validated for use in ERA monitoring programs (Bucheli and Fent, 1995; Van der Oost et al., 2003), for all these reasons; analysis of CYP1A has been carried out in the present work.

CYP1A is dependent on mixed-function oxygenase (MFO) or monooxygenases. MFO enzyme assays include the ethoxyresorufin-Odeethylase (EROD). MFOs are a family of inducible enzymes which oxidize, by single oxygen addition, natural and anthropogenic chemicals. Their metabolic function assists in the excretion of nonpolar compounds 
(Martin et al., 1985). A number of chemical classes are known inducing agents. The most potent inducers are lipid-soluble, planar compounds of $3 \mathrm{~A} \times 10$ A size.

Numerous studies have demonstrated an increase in the CYP1A protein levels in various species of fish after exposure to organic pollutants. Notably, the action of PAHs, PCBs, PCDDs and PCDFs per se caused a significant or a very strong increase (500\% of control) in CYP1A content (Van der Oost et al., 2003). Although the main function of the cytochrome P450-dependent monooxygenase system is to convert relatively insoluble organic compounds to soluble metabolites, the resulting metabolites may be less or more toxic than the parent compound activation of cytochrome P450 and it can also promote the CYP1A detoxifying activity. Especially, cytochrome P4501A-dependent oxidation is found to be responsible for the activation of PAHs and PCBs to the reactive intermediates that ultimately result in toxicity, carcinogenicity and mutagenicity (Arinç and Sen, 1999).

Increased EROD activity is frequently observed in fish captured from contaminated waters (Lima et al., 2008; Pathiratne et al., 2008; Lu et al., 2010). EROD levels in fish are usually highest near the contaminant of effluent source, and decreased at sites farther from the source. EROD or AHH activity has been measured in a wide variety of fish species; however, several species show little or no EROD induction (Kloepper-Sams and Benton, 1994; Almroth et al., 2008) or show an inhibition of EROD activity (Mondon et al., 2001; Solé et al., 2006).

Detailed light and microscopic studies of fish liver indicate that the morphology of the liver includes at least 10 resident cell types of CYP1A. By far the most numerous, hepatocytes occupy about $80-85 \%$ of the liver volume. Other cell types include endothelial cells, biliary epithelial cells of preductules, ductules and intrahepatic ducts, exocrine pancreatic cells, and centroacinar and ductular cells of exocrine pancreas have shown CYP1A immunoreactivity when fish have been exposed to different contaminants (Desantis et al., 2005; Ortiz-Delgado et al., 2005). The type of inducing agent, dose, species variations, water temperature, reproductive stage and sex may affect the distribution of constitutive and inducible cytochrome $\mathrm{P} 450$ forms. Induction responses in endocrine organs may affect important and delicate functions (Husoy et al., 1994).

Vertebrate animals from environments free of pollutant inducers show little or no detectable CYP1A in gills, while animals from contaminated sites express elevated levels of CYP1A (Jönsson et al., 2004; Jimenez-Tenorio et al., 2008). EROD activity in fish liver has been widely studied and considered a good pollution biomarker but CYP1A activity in gills has received less attention (Costa et al., 2011; Nogueira et al., 2011).

The estuary of "Ria de Huelva" has been world-famous as one of the most contaminated estuaries by heavy metals in the world. The contaminant load transported by the Tinto and Odiel rivers to the Ría de Huelva and industrial activities (petrochemical, refining, fertilizer and mining) are the main causes (Sainz et al., 2005). Related to the first contribution, the contaminants come from upstream of Tinto and Odiel rivers where there are mines belonging to the Iberian Pyrite Belt (IPB), an important metal-rich sulfide deposit (Ruiz Cánovas et al., 2012; Galván et al., 2013), and which represent more than $99 \%$ of the total metal content in the estuary (Pérez-López et al., 2011).

The commercially exploited Senegal sole, Solea senegalensis (Kaup, 1858), represents a suitable bioindicator species for assessment of Huelva estuary pollution. Predominantly littoral, S. senegalensis is a benthic marine species well adapted to warm climates and is commonly exploited in extensive aquaculture production in Spain and Portugal (Drake et al., 1984; Dinis, 1992) and has been used in field and laboratory toxicity assays being a sensitive specie to pollutants (Costa et al., 2009; Oliva et al., 2009).

The aim of this work was to study the effect of pollution on the CYP1A cellular induction and EROD activity in liver and gills of S. senegalensis and the correlations with heavy metal and PAHs. Results from the current study can also be used to evaluate whether any one measure of CYP1A is more suited for use in monitoring programs.

\section{Material and methods}

\subsection{Sampling sites and fish collection}

The Tinto and Odiel Rivers flow together to the Atlantic Ocean forming a common canal known as Canal Padre Santo belonging to the Ria de Huelva.

Three sampling sites were selected in this area of the southwest coast of Spain (Fig. 1): Odiel River ( $\left.37^{\circ} 13.5^{\prime} \mathrm{N} 6^{\circ} 57.2^{\prime} \mathrm{W}\right)$, Tinto River $\left(37^{\circ} 12.5^{\prime} \mathrm{N} 6^{\circ} 56^{\prime} \mathrm{W}\right.$ ) and Canal del Padre Santo ( $37^{\circ} 09.9^{\prime} \mathrm{N} 6^{\circ} 54.8^{\prime} \mathrm{W}$ ).

Four samplings were realized from October 2004 to May 2006, two of them were realized in autumn (October 2004 and October 2005) and the others were realized in spring (April 2005 and May 2006).

Specimens of Senegal sole S. senegalensis (Kaup, 1858) were collected at each sampling site for each sampling period and were transported in aerated tanks to Mazagon's port (Huelva). A total of 97 (mass: $125.04 \pm 27.12 \mathrm{~g}$, length: $23.14 \pm 1.8 \mathrm{~cm}$ ) fish were dissected (Odiel River $n=43$; Tinto River $n=32$, Canal Padre Santo $\mathrm{n}=20$ ) and samples of liver and gills of each fish were taken. Fish tissue samples were transported to the laboratory in nitrogen liquid and stored at $-80{ }^{\circ} \mathrm{C}$. Twelve specimens of S. senegalensis (mass: $182.52 \pm 23.89 \mathrm{~g}$, length $25.27 \pm 0.78 \mathrm{~cm}$ ) used as unpolluted or control fish, were obtained from the aquaculture facilities of the Faculty of Marine and Environmental Sciences (University of Cadiz, Spain).

\subsection{Heavy metal analysis in fish, sediments and water}

Collected fish were dissected and tissue samples from liver and gills were taken. Freeze-dried samples of liver and gills were acid digested by microwave heating using $\mathrm{HNO}_{3}$ and $\mathrm{H}_{2} \mathrm{O}_{2}$. Metal concentrations of digested tissue samples were analyzed by ICP-MS and ICP-AES. The accuracy of methodology applied was satisfactorily evaluated using DOLT-3 (dogfish liver) and DORM-2 (dogfish muscle) certified reference materials (Vicente Martorell et al., 2009).

Surface sediment samples $(2-20 \mathrm{~cm})$ were collected using a crab and stored in polyethylene bags at $-4{ }^{\circ} \mathrm{C}$. Fine particle-size fractions

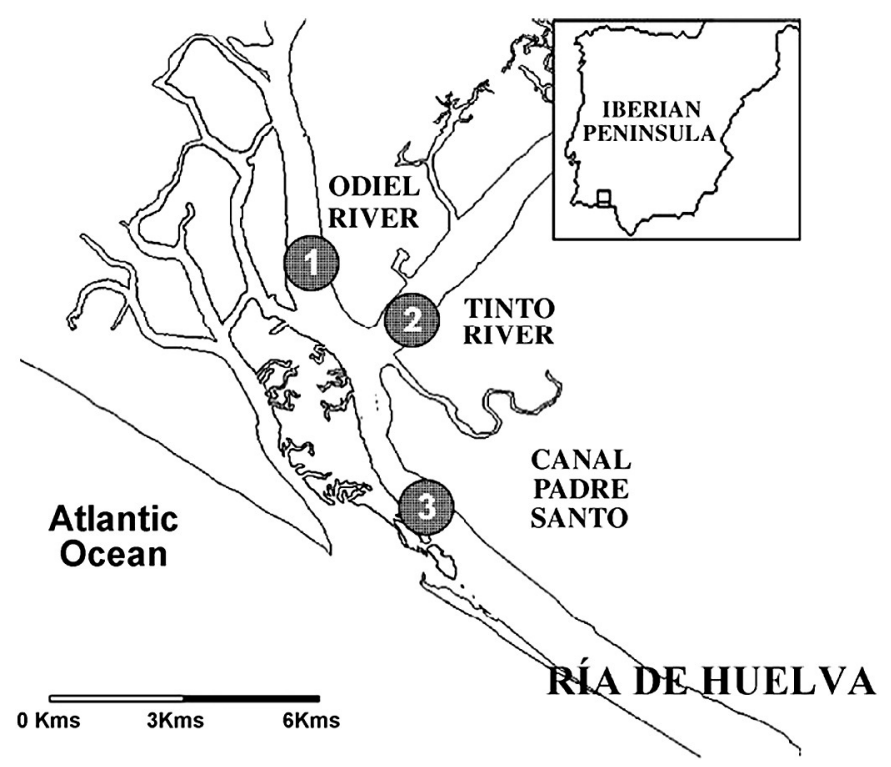

Fig. 1. Location map of sampling sites in Huelva (Spain): 1 (Odiel river); 2 (Tinto river); 3 (Canal Padre Santo). 
were obtained from the dried ground and sieved sediments. The BCR sequential extraction (exchangeable, reducible, oxidizable and residue fraction) procedure was applied (Davidson et al., 1999) and speciation and total concentrations of metals were evaluated by using ICP-AES or AAS. NIST 1649a certified reference estuarine sediment was used for analysis validation (Vicente Martorell et al., 2009).

Water sample collection was carried out using a peristaltic bomb and no filtered and filtered samples were obtained in situ by using $0.45 \mu \mathrm{m}$ Calyx Capsule MSI filter connected online when required. Total metal, particulate metal fraction and dissolved metal fractions (labile organic, labile inorganic, moderately labile inorganic, moderately labile organic and no labile dissolved metal) were analyzed by stripping voltammetry after acid digestion. Dissolved metal speciation was carried out by metal fractionation to different $\mathrm{pH}$ distinguished among labile inorganic and organic metal, moderately labile inorganic and organic metal and inert fraction. In addition, particulate and organic and inorganic dissolved arsenic species were evaluated by using hydride generation and AAS, with an operational discrimination among fractions. Analytical methods were checked against CRM 505 certified reference estuarine water.

\subsection{Analytical procedure for PAHs in sediments and gills of S. senegalensis}

16 PAHs identified by the United States Environmental Protection Agency (EPA) and the World Health Organization (WHO) as priority pollutants have been analyzed in samples of sediment and tissues of S. sengalensis. The 16 PAHs (total PAHs - TPAHs) have been divided into two different categories: low molecular weight PAHs - LPAHs (naphthalene, acenaphthylene, acenaphthene, fluorene, phenantherene, anthracene, fluoranthene and pyrene) and high molecular weight PAHs - HPAHs (benzo(a)anthracene, chrysene, benzo(b)fluoranthene, benzo(k)fluoranthene, benzo(a)pyrene, dibenzo(a,h)anthracene, benzo(g,h,i)perylene, indeno(1,2,3-cd)pyrene).

PAH analysis in sediment was based on the analytical procedure proposed by the USEPA $(1996,2000)$. Approximately 2-4 g of sediment was weighed and treated with anhydrous $\mathrm{Na}_{2} \mathrm{SO}_{4}$. The samples were Soxhlet-extracted with $10 \mathrm{~mL}$ dichloromethane-acetone $(8: 2 \mathrm{v} / \mathrm{v})$ for $24 \mathrm{~h}$ ( 6 cycles per hour). The extracts were purified on florisil columns, and the PAHs were eluted with $100 \mathrm{~mL}$ dichloromethane-hexane $(2: 8 \mathrm{v} / \mathrm{v})$. The extract was concentrated to $1 \mathrm{~mL}$ using a rotary evaporator after changing the solvent from dichloromethane-hexane to acetonitrile. $\mathrm{Na}_{2} \mathrm{SO}_{4}$ was of analytical grade and dichloromethane, hexane, acetone and acetonitrile were HPLC grade. The composition and concentration of 16 different PAHs was determined by HPLC. A standard solution, SUPELCO 47940-u PAH mix in acetonitrile (containing 16 individual PAHs), was used for quantification.

Gills were freeze-dried in a lyophilizer, ground and homogenized. PAHs concentration in liver could not be measured due to the liver sample size. The procedures for tissue PAHs analyses were based on the analytical method 3564C and 3620B proposed by USEPA (1996, 2000a), which according to Cheung et al. (2007) are appropriate and optimum for analyzing PAHs in fish samples. Briefly, the samples were Soxhletextracted using a mixture of acetone and dichloromethane for $24 \mathrm{~h}$; the extracts were purified on Florisil columns; and concentrated by rotary evaporation. The composition and concentration of 16 different PAHs were determined by gas chromatography-mass spectrometry (GC-MS/MS). A reference material (soil LGC6182) was analyzed, with 81-102\% of certified values of PAHs obtained, excepting benzo(g,h,i) perylene. Average relative percent difference between triplicates (14\%) was within acceptable limits, according to Levengood and Schaeffer (2011).

\subsection{Analytical procedure for PAH metabolites in S. senegalensis tissues}

Post-mitochondrial supernatant (PMS) of liver and gills were further diluted in methanol 50\% to 1:400 for FF measurement. Fluorescent readings were performed for naphthalene-type metabolites at excitation/ emission 290/335 nm, for benzo(a)pyrene-type metabolites readings were made at $380 / 430 \mathrm{~nm}$, for pyrene-type metabolites readings were done at 341/383 and for phenanthrene-type metabolites readings at 256/380. Liver cytosol metabolites are reported on the basis of milligram protein as previously adapted by Gagnon and Holdway (2000).

\subsection{EROD activity}

EROD activity was quantified in S9 fraction of liver and gills by fixed wavelength fluorescence detection (Jasco FP-6200 pectrofluorometer) as described by Burke and Mayer (1974). The enzyme activity was expressed in $\mathrm{pmol} / \mathrm{min} / \mathrm{mg}$ of protein.

\subsection{Immunohistochemical analysis of CYP1A}

Sections of $6 \mu \mathrm{m}$ thickness were prepared from paraffin-embedded tissues. The sections, after blocking of unspecific binding sites, were incubated overnight in a humid chamber at room temperature with the primary polyclonal anti fish-CYP1A antibody (CP-226 Biosense Laboratories) at a dilution of $1: 250$. For further staining, the $A B C$ kit (Vectastain, USA) including a biotinylated anti-mouse IgG secondary antibody was applied. Sections incubated with normal fish serum instead of the primary antibody were used as negative controls.

During evaluation of staining intensity of CYP1A in histological sections, we assigned values of 0 (negative), 0.5 (negative/mild), 1 (mild), 1.5 (mild/moderate), 2 (moderate), 2.5 (moderate/high), and 3 (high).

Occurrence of CYP1A in cells of interest in the different tissues analyzed was calculated as the relative frequency of stained cells, we assigned values of 0 (no staining seen), 1 (rare), 2 (multifocally), 3 (frequent).

Frequency (percentage) of S. senegalensis specimens with CYP1Aassociated staining was expressed as the fraction of individuals

Table 1

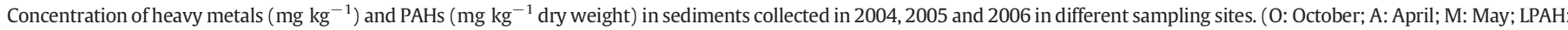
low molecular weight PAH; HPAH: high molecular weight PAH; TPAH: total PAH.)

\begin{tabular}{|c|c|c|c|c|c|c|c|c|c|c|c|c|}
\hline & \multicolumn{4}{|l|}{ Odiel } & \multicolumn{4}{|l|}{ Tinto } & \multicolumn{4}{|c|}{ Canal Padre Santo } \\
\hline & O '04 & A '05 & O '05 & M '06 & O '04 & A '05 & O '05 & M '06 & O '04 & A '05 & O '05 & M '06 \\
\hline As & 85.15 & 615.43 & 375.03 & 246.24 & 198.79 & 284.29 & 530.39 & 343.86 & 237.74 & 599.81 & 486.77 & 211.98 \\
\hline $\mathrm{Pb}$ & 136.76 & 1166.67 & 817.35 & 238.87 & 246.15 & 358.38 & 974.95 & 404.33 & 343.25 & 879.06 & 1028.15 & 269.64 \\
\hline $\mathrm{Cd}$ & 3.43 & 33.20 & 15.99 & 5.08 & 4.84 & 5.11 & 18.30 & 5.41 & 3.87 & 8.93 & 14.04 & 1.50 \\
\hline $\mathrm{Cu}$ & 1115.70 & 3333.63 & 2157.68 & 1829.17 & 2099.49 & 1470.11 & 1513.77 & 2505.34 & 2325.75 & 2469.38 & 2652.79 & 1412.51 \\
\hline $\mathrm{Fe}$ & $44,689.42$ & $85,647.31$ & $67,720.90$ & $59,015.01$ & $84,244.36$ & $70,159.77$ & $189,673.49$ & $74,340.571$ & $75,822.71$ & $71,947.57$ & $55,312.81$ & $61,426.78$ \\
\hline $\mathrm{Zn}$ & 602.94 & 1736.95 & 1308.01 & 966.92 & 1506.68 & 738.41 & 1161.15 & 1054.56 & 1327.12 & 1489.18 & 1569.12 & 1337.25 \\
\hline LPAH & 0.51 & 0.97 & 0.94 & 0.96 & 0.87 & 0.67 & 1.12 & 1.36 & 1.42 & 1.07 & 0.16 & 4.62 \\
\hline HРAH & 0.50 & 0.22 & 1.18 & 0.75 & 0.61 & 0.41 & 0.52 & 1.00 & 1.47 & 0.54 & 0.10 & 0.32 \\
\hline ТРAH & 1.01 & 1.19 & 2.13 & 1.72 & 1.48 & 1.09 & 1.64 & 2.36 & 2.89 & 1.61 & 0.27 & 4.95 \\
\hline
\end{tabular}


Table 2

Concentration of heavy metals ( $\mathrm{mg} \mathrm{kg}^{-1}$ ) in water collected in 2004, 2005 and 2006 in different sampling sites (O: October; A: April; M: May).

\begin{tabular}{|c|c|c|c|c|c|c|c|c|c|c|c|c|}
\hline & \multicolumn{4}{|l|}{ Odiel } & \multicolumn{4}{|l|}{ Tinto } & \multicolumn{4}{|c|}{ Canal Padre Santo } \\
\hline & O '04 & A '05 & O '05 & M '06 & O '04 & A '05 & O '05 & M '06 & O '04 & A '05 & O '05 & M '06 \\
\hline As & 4.70 & 4.10 & 9.30 & 2.90 & 3.00 & 6.00 & 7.50 & 5.30 & 2.80 & 3.20 & 6.20 & 2.60 \\
\hline $\mathrm{Pb}$ & 3.70 & 6.10 & 17.80 & 6.20 & 5.70 & 7.40 & 3.50 & 5.00 & 2.60 & 5.20 & 5.70 & 6.20 \\
\hline $\mathrm{Cd}$ & 1.30 & 3.10 & 1.60 & 8.90 & 1.30 & 4.50 & 2.20 & 6.80 & 0.80 & 0.80 & 0.70 & 1.70 \\
\hline $\mathrm{Cu}$ & 34.50 & 57.20 & 56.70 & 54.70 & 37.10 & 68.00 & 47.30 & 72.40 & 20.90 & 27.80 & 22.20 & 57.70 \\
\hline $\mathrm{Zn}$ & 80.60 & 191.20 & 124.90 & 381.60 & 324.80 & 198.30 & 119.80 & 252.00 & 121.50 & 52.80 & 49.80 & 108.70 \\
\hline
\end{tabular}

examined that exhibited some degree of staining (i.e., 0.5 or above) in the cell or tissue of interest.

\subsection{Statistical analysis}

Statistical analyses were performed using the statistical software package STATISTICA (data analysis software system) version 7 (2004, Statsoft, Inc. USA).

For each data set, the assumptions of an analysis of variance (ANOVA), normality and equal variance, were checked using ShapiroWilks and Levene tests, respectively. If the data set met assumptions, one-way ANOVA was conducted and where significant, a post-hoc mean comparison test (Tukey's test) was realized. If data sets did not meet assumptions, Kruskal-Wallis and Mann Whitney (one-tail) tests to determine significant differences were used. To analyze the correlation between biomarkers and heavy metals, Pearson and Spearman correlation tests were used. All statistical analyses were conducted at an alpha level of 0.05 .

\section{Results and discussion}

\subsection{Pollutants}

The estuary of Ria de Huelva has been world-famous as one of the most heavy metal contaminated estuaries in the world. The contaminant load transported by the Tinto and Odiel Rivers to the Ría de Huelva and industrial activities (petrochemical, refining, fertilizer and mining) are the main causes (Sainz et al., 2005).

The high values for all metals analyzed in sediments were obtained for sampling of 2005 , coinciding with a period of low rainfalls (Table 1). The order of metals from higher to lower mean content in the sediment of this estuary was: $\mathrm{Cu}>\mathrm{Zn}>\mathrm{Pb}>\mathrm{As}>\mathrm{Cd}$.

The data about distribution of metals in fractions of BCR procedure was presented in the work realized by Vicente-Martorell et al. (2008). The results did not show significant variations between sampling sites, except for $\mathrm{Cu}$ that has higher reducible fraction in Canal Padre Santo. The results obtained were compared with Canadian sediment quality guidelines (ISQG, interim marine sediment quality guidelines and PEL, probable effects levels) and NOAA guidelines for the protection of aquatic life (ERL, level of effects range low and ERM, level of effects range medium). All metal studies showed higher concentrations than in the quality criteria, except $\mathrm{Pb}$ which had some lower values than in the ERM guideline on 2004 autumn.

Generally, content of metals in Tinto and Odiel water (Table 2) was higher than in the Canal Padre Santo site. The metal concentrations in water can be arranged as follows (higher content to lower content): $\mathrm{Zn}>\mathrm{Cu}>\mathrm{Pb} \approx \mathrm{As}>\mathrm{Cd}$.

High $\mathrm{Cu}$ and $\mathrm{Zn}$ levels were observed in liver tissue according to the higher total content and greater availability of metals both in the water and sediment. The liver samples showed the following average accumulation ranking: $\mathrm{Fe}>\mathrm{Cu}>\mathrm{Zn}>\mathrm{As}>\mathrm{Cd}>\mathrm{Pb}$ (Table 3), although it was noted that a significant value for sampling in April 2005 with a higher copper content than iron, was found only in Odiel river $(\mathrm{Cu}=$ $609.73 \mathrm{mg} \mathrm{kg}^{-1}$; Fe $\left.0476.66 \mathrm{mg} \mathrm{kg}^{-1}\right)$. Significant correlation $(\mathrm{r}=$ $0.732, \mathrm{p}=0.039$ ) was found between $\mathrm{Cu}$ concentration in liver and $\mathrm{Cu}$ concentration in sediment. Again, the metal with highest concentration in the gills was Fe; the gills showed the following average accumulation ranking: $\mathrm{Fe}>\mathrm{Zn}>\mathrm{Cu}>\mathrm{As}>\mathrm{Pb}>\mathrm{Cd}$ (Table 4). As can be seen, this ranking shows some differences between tissues. Conversely, significant differences among sampling sites were not found.

The higher concentration of PAHs (LPAHs) was observed in the sediment of Canal Padre Santo (Table 1), this is the closest sample point to the oil refinery La Rabida. Roy et al. (2003) observed higher PAHs of low molecular weight in coal oil point ( $\mathrm{COP}$ ) sediments than high molecular PAHs. This is consistent with previous studies showing that natural petroleum seeps tend to have higher concentrations of lower molecular weight aromatic hydrocarbons (Spies et al., 1980).

To establish the contamination grade for PAHs in the different sampling sites, the levels of PAHs observed have been compared with the Holland Environmental Quality Criteria for Marine Sediments (Kamer, 1994). This criteria is established on the basis of the summatory of 10 PAHs (naphthalene, phenanthrene, anthracene, fluoranthene, chrysene, benzo(a)anthracene, benzo(k)fluoranthene, benzo(b)fluoranthene, benzo(g)perylene and indene). The summatory of those PAHs in Odiel River was $0.68 \mathrm{mg} / \mathrm{kg}, 0.82 \mathrm{mg} / \mathrm{kg}$ in the Tinto River and $1.81 \mathrm{mg} / \mathrm{kg}$ dry weight in Canal Padre Santo. Therefore, based on the Holland Environmental Quality Criteria for Marine Sediments (Kamer, 1994), Odiel and Tinto Rivers would be classified as not contaminated or slightly contaminated sites and Canal Padre Santo as a moderately contaminated site.

PAHs more abundant in sediment have been LPAHs (Table 1). With a significant correlation observed between phenanthrene-type metabolites in liver and fluorene concentration in sediments $(\mathrm{p}=0.028 ; \mathrm{r}=$

Table 3

Average concentration of heavy metals $\left(\mathrm{mg} \mathrm{kg}^{-1}\right)$ in liver of S. senegalensis collected in 2004, 2005 and 2006 (O: October, A: April, M: May).

\begin{tabular}{|c|c|c|c|c|c|c|c|c|c|c|c|c|}
\hline & \multicolumn{4}{|l|}{ Odiel } & \multicolumn{4}{|l|}{ Tinto } & \multicolumn{4}{|c|}{ Canal Padre Santo } \\
\hline & O '04 & A '05 & O '05 & M '06 & O '04 & A '05 & O '05 & M '06 & O '04 & A '05 & O '05 & M '06 \\
\hline As & 6.38 & 6.78 & 8.71 & 14.27 & a & 3.18 & 4.79 & 60.51 & a & $\mathrm{b}$ & 6.24 & $\mathrm{~b}$ \\
\hline $\mathrm{Pb}$ & 1.62 & 1.20 & 1.65 & 1.51 & a & 0.70 & 1.76 & 1.50 & a & $\mathrm{b}$ & 1.41 & b \\
\hline $\mathrm{Cd}$ & 0.96 & 2.65 & 1.22 & 2.69 & a & 0.84 & 1.85 & 1.99 & a & $\mathrm{b}$ & 1.76 & $\mathrm{~b}$ \\
\hline $\mathrm{Cu}$ & 230.20 & 609.73 & 416.73 & 576.10 & a & 236.89 & 386.37 & 349.44 & a & $\mathrm{b}$ & 546.04 & $\mathrm{~b}$ \\
\hline $\mathrm{Fe}$ & 480.83 & 476.66 & 555.40 & 646.54 & a & 316.38 & 597.14 & 411.46 & a & $\mathrm{b}$ & 661.88 & b \\
\hline $\mathrm{Zn}$ & 122.90 & 115.54 & 95.82 & 70.49 & a & 106.87 & 75.84 & 76.93 & a & $\mathrm{b}$ & 81.40 & $\mathrm{~b}$ \\
\hline
\end{tabular}

a An instrumental failure caused the damage of the samples.

b No S. senegalensis were captured in Canal Padre Santo during spring season.

c PAHs concentration in liver could not be measured due to liver sample size. 
Table 4

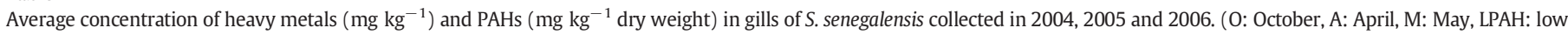
molecular weight PAH, HPAH: high molecular weight PAH, TPAH: total PAH.)

\begin{tabular}{|c|c|c|c|c|c|c|c|c|c|c|c|c|}
\hline & \multicolumn{4}{|l|}{ Odiel } & \multicolumn{4}{|l|}{ Tinto } & \multicolumn{4}{|c|}{ Canal Padre Santo } \\
\hline & O '04 & A '05 & O '05 & M '06 & O '04 & A '05 & O '05 & M '06 & O '04 & A '05 & O '05 & M '06 \\
\hline As & 4.36 & 3.70 & 3.36 & 18.39 & $\mathrm{a}$ & 4.418 & 3.86 & 57.41 & $\mathrm{a}$ & $\mathrm{b}$ & 3.04 & $\mathrm{~b}$ \\
\hline $\mathrm{Pb}$ & 4.08 & 1.96 & 4.51 & 3.04 & a & 4.47 & 4.53 & 9.40 & $\mathrm{a}$ & b & 2.97 & $\mathrm{~b}$ \\
\hline $\mathrm{Cd}$ & 0.41 & 0.59 & 0.46 & 0.42 & a & 0.59 & 0.82 & 0.57 & $\mathrm{a}$ & $\mathrm{b}$ & 0.50 & $\mathrm{~b}$ \\
\hline $\mathrm{Cu}$ & 5.16 & 8.43 & 6.99 & 10.21 & $\mathrm{a}$ & 17.40 & 9.00 & 29.26 & $\mathrm{a}$ & $\mathrm{b}$ & 6.43 & $\mathrm{~b}$ \\
\hline $\mathrm{Fe}$ & 402.44 & 232.60 & 296.68 & 384.36 & $\mathrm{a}$ & 363.55 & 409.96 & 807.86 & a & b & 294.27 & $\mathrm{~b}$ \\
\hline Zn & 66.70 & 68.78 & 89.43 & 64.13 & a & 81.90 & 67.38 & 81.59 & $\mathrm{a}$ & b & 66.86 & $\mathrm{~b}$ \\
\hline LPAH & 1.33 & 0.90 & 0.00 & 0.12 & 0.00 & 0.16 & 0.18 & 0.37 & 0.66 & b & 0.00 & b \\
\hline $\mathrm{HPAH}$ & 0.09 & 2.95 & 0.00 & 0.00 & 0.00 & 0.00 & 0.35 & 0.18 & 1.69 & b & 0.31 & b \\
\hline ТРAH & 1.43 & 3.85 & 0.00 & 0.12 & 0.00 & 0.16 & 0.54 & 0.56 & 2.35 & b & 0.31 & b \\
\hline
\end{tabular}

a An instrumental failure caused the damage of the samples.

b No S. senegalensis were captured in Canal Padre Santo during spring season.

Table 5

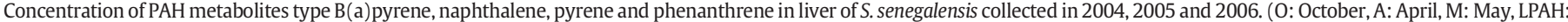
low molecular weight PAH, high molecular weight PAH, total PAH.) B(a)pyrene and pyrene (ng equivalent/mg protein); naphthalene and phenanthrene ( $\mu$ g equivalent/mg protein).

\begin{tabular}{|c|c|c|c|c|c|c|c|c|c|c|c|c|}
\hline & \multicolumn{4}{|l|}{ Odiel } & \multicolumn{4}{|l|}{ Tinto } & \multicolumn{4}{|c|}{ Canal Padre Santo } \\
\hline & $\mathrm{O}^{\prime} 04$ & A '05 & O '05 & M '06 & O '04 & A '05 & O '05 & M '06 & O '04 & A '05 & O '05 & M '06 \\
\hline B(a)pyrene & 0.162 & 0.641 & 0.694 & 0.404 & 0.501 & 2.027 & 1.086 & 1.276 & 0.000 & $\mathrm{a}$ & 0.002 & $\mathrm{a}$ \\
\hline Naphthalene & 2.598 & 4.357 & 4.333 & 2.916 & 4.093 & 5.566 & 4.537 & 6.846 & 3.751 & $\mathrm{a}$ & 3.659 & $\mathrm{a}$ \\
\hline Pyrene & 39.045 & 54.710 & 51.252 & 39.113 & 44.241 & 70.424 & 53.713 & 76.830 & 63.625 & $\mathrm{a}$ & 43.092 & $\mathrm{a}$ \\
\hline Phenanthrene & 0.411 & 0.366 & 0.402 & 0.428 & 0.310 & 0.405 & 0.417 & 0.440 & 0.454 & $\mathrm{a}$ & 0.408 & $\mathrm{a}$ \\
\hline
\end{tabular}

a No S. senegalensis were captured in Canal Padre Santo during spring season.

0.687), this could imply a higher accumulation of LPAHs in liver of S. senegalensis (not measured) which is in agreement with data reported in other fish (Narbonne et al., 1999; Salazar-Coria et al., 2007). PAHs more abundant in sediment have been LPAHs but gills presented differences in LPAH and HPAH concentrations related to the different seasons and sampling sites (Table 4). Pyrene metabolite types showed the highest concentrations in gills. Measuring contaminant levels in aquatic organisms does address the question of bioavailability; however, because PAHs exert their toxicity following biotransformation to toxic metabolites, assessment of tissue concentrations of parent compounds alone is insufficient. PAH metabolites (Tables 5 and 6) detected in fish have been applied as a biomarker of exposure to both pyrogenic and petrogenic PAH. It has proven to be a simple and sensitive method for screening PAH contamination in fish (Aas et al., 2000).

The number of rings explains the influence of the metabolic velocities of PAHs. Thus, the decrease was faster for PAHs of low molecular weight (anthracene and phenanthrene, which are rapidly released in the aqueous compartment) than for PAHs of high molecular weight (pyrene and benzo[a]pyrene), which are strongly adsorbed in sediment particles. When the rate of desorption from particles and humic material is rapid, uptake from interstitial water seems to prevail as for LPAHs; when desorption rate is slow compared with the ingestion rate, then ingestion becomes more competitive as for HPAHs (Narbonne et al., 1999).

\subsection{Liver EROD activity}

In this study the higher liver EROD activity was observed in autumn 2005 (Fig. 2A) coinciding with the higher concentration of heavy metals in sediments. However no correlation was established between EROD activity in liver and heavy metal concentration in sediments and/or liver but a significant correlation was established between copper labile organic fraction in water and EROD $(p=0.030, r=0.682)$. An explanation for this relation is $\mathrm{Cu}$ concentration in water appeared associated with moderately labile inorganic and organic dissolved fractions with an important percentage of labile metal during autumn samplings, mainly in Tinto and Canal Padre Santo sites, being more available. Otherwise, an increase has been observed in labile inorganic dissolved fraction of $\mathrm{Cu}$ in Canal Padre Santo water during samplings in 2005 (56$61 \%$ ) (Vicente Martorell et al., 2009). Because copper concentrations were extremely high in the sediment and water and in the liver of S. senegalensis from Tinto River and Padre Santo Canal, special attention should be given to $\mathrm{Cu}^{2+}$ concentrations.

Copper is a trace element that plays a fundamental role in the biochemistry of all organisms. The high $\mathrm{Cu}^{2+}$ concentrations appear to be toxic to fish exerting cytotoxicity, generating oxidative stress and cellular damage (Gaetke and Chow, 2003). Cvec (1990) and Toccane and Teissie (1990) investigated the effects of the long-term exposure of

Table 6

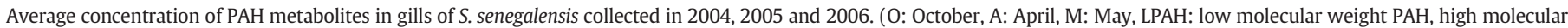
weight $\mathrm{PAH}$, Total $\mathrm{PAH}$.) B(a)pyrene and pyrene (ng equivalent/mg protein); naphthalene and phenanthrene ( $\mu$ g equivalent/mg protein).

\begin{tabular}{|c|c|c|c|c|c|c|c|c|c|c|c|c|}
\hline & \multicolumn{4}{|l|}{ Odiel } & \multicolumn{4}{|l|}{ Tinto } & \multicolumn{4}{|c|}{ Canal Padre Santo } \\
\hline & O '04 & A '05 & O '05 & M '06 & O '04 & A '05 & O '05 & M '06 & O '04 & A '05 & O '05 & M '06 \\
\hline $\mathrm{B}(\mathrm{a})$ pyrene & 0.086 & 0.042 & 0.023 & 0.154 & 0.000 & 0.022 & 0.038 & 0.080 & 0.099 & $a$ & 0.090 & a \\
\hline Naphthalene & 0.050 & 0.033 & 0.032 & 0.098 & 0.057 & 0.030 & 0.055 & 0.087 & 0.067 & $\mathrm{a}$ & 0.071 & $\mathrm{a}$ \\
\hline Pyrene & 0.819 & 0.122 & 0.134 & 0.007 & 0.013 & 0.171 & 0.237 & 0.992 & 1.064 & a & 0.873 & $\mathrm{a}$ \\
\hline Phenanthrene & 0.001 & 0.007 & 0.008 & 0.007 & 0.000 & 0.003 & 0.007 & 0.008 & 0.003 & $a$ & 0.007 & $a$ \\
\hline
\end{tabular}

a No S. senegalensis were captured in Canal Padre Santo during spring season. 

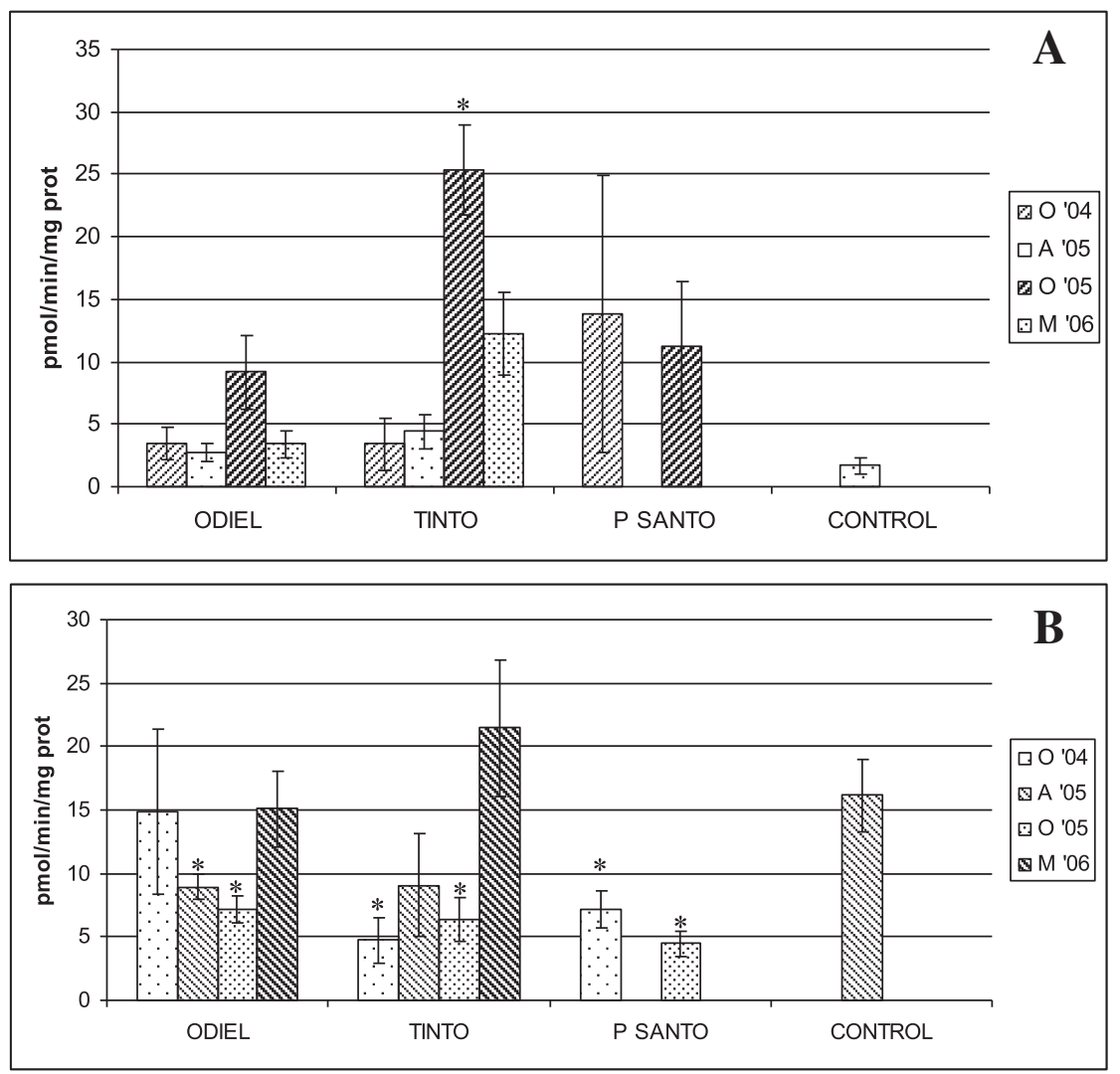

Fig. 2. EROD activity in liver (A) and gills (B) of S. senegalensis from different sampling sites. Asterisks denote that means are significantly different from the control ( $<<0.05$ ).

phospholipid membranes on heavy metals. They concluded that the effects of free ions can change the charge on the membrane surface and can interact with the proteins, inducing toxic effects.

High EROD activity in liver related with copper concentration agrees with the results observed by Henczova et al. (2008) in silver carp treated with $1 \mathrm{mg} \mathrm{L}^{-1}$ and $10 \mathrm{mg} \mathrm{L}^{-1} \mathrm{Cu}^{2+}$ where EROD (4-fold) and the Cyt P450 content were significantly enhanced after treatments. On the other hand, inhibitory effects of metals on EROD activity have been observed by several authors. In vivo and in vitro studies concerning other fish species demonstrated liver EROD activity inhibition by $\mathrm{Cu}$ (Oliveira et al., 2004; Sanchez et al., 2005), however, Almroth et al. (2008) observed no EROD activity differences between a heavy metal and PAH contaminated site.

In an experiment with heavy metals, Korashy and El-Kadi (2008) observed in a co-exposure of HepG2 human cells with either Hg2 + or $\mathrm{Pb} 2+$, at all concentrations tested a significant reduction of the magnitude of CYP1A1 induction by TCDD, surprisingly, the highest concentration of $\mathrm{Cu} 2+$ further increased the TCDD-induced CYP1A1 activity levels and EROD activity. Those observations are in agreement with those of Vakharia et al. (2001), who reported that a translational but not transcriptional mechanism is involved in the modulation of CYP1A1 protein induction by heavy metals in HepG2 cells.

On the other hand, PAHs exert their toxicity following biotransformation to toxic metabolites; assessment of tissue concentrations of parent compounds alone is insufficient. PAH metabolites detected in fish have been applied as a biomarker of exposure to both pyrogenic and petrogenic $\mathrm{PAH}$. It has proven to be a simple and sensitive method for screening PAH contamination in fish (Aas et al., 2000).

The use of FAC (Fluorescent Aromatic Compounds) techniques to analyze pollutant metabolites, as a biochemical endpoint, has proved an effective method of determining exposure to xenobiotic compounds (Aas et al., 2000; Roy et al., 2003). Other studies have demonstrated that increasing levels of PAH contaminants in sediments, diet and water result in higher levels of FACs in fish exposed to these contaminants (Ortiz-Delgado et al., 2008; Vieira et al., 2009).

PAH concentrations observed in hepatic tissue were very low, zero or undetectable in most samples (data unpublished), for this reason correlations have been conducted only between $\mathrm{PAH}$ metabolites in liver and CYP1A (catalytic activity).

In this work a significant correlation $(p=0.003, r=0.360)$ was established between EROD activity and phenanthrene-type metabolites in liver.

Shailaja and D'Silva (2003) and Oliveria et al. (2007) also observed in Oreochromis mossambicus and Liza aurata respectively exposed to phenanthrene an EROD activity higher than in the control value.

Induction of CYP1A in fish by small molecular size PAHs (having $\leq 4$ fused aromatic rings) such as chrysene, phenanthrene, pyrene and naphthalene is irregular and species dependent (Van der Weiden et al., 1994; Bols et al., 1999). This could be due to intrinsic variations in the affinity of the aryl-hydrocarbon receptor (AhR) of different fish species to small molecular size PAH compounds.

\subsection{Gill EROD activity}

There are numerous previous studies on EROD activity in liver but few studies have been conducted in gills (Mdegela et al., 2006; Ortiz-Delgado et al., 2008; Nahrgang et al., 2010) and only a few of them in relation with heavy metals (Mondon et al., 2001; Jönsson et al., 2004).

Despite the lower CYP1A catalytic rates in gills, its higher relative perfusion rates compared with other organs such as liver indicates that this organ may represent a significant biotransformation site. Thus the biotransformation in the gills may influence the toxicity of waterborne chemicals (Ortiz-Delgado et al., 2007). Xenobiotics can be 
metabolized at significant rates during the passage through the branchial epithelium.

A significant decrease $(\mathrm{p}<0.05)$ of EROD activity was observed in all three sampling sites in October 2005 and in Tinto River and Canal del Padre Santo in October 2004. In April 2005 a significant decrease of EROD activity was also observed in Odiel River (Fig. 2B). No correlations were observed between PAH concentrations (sediments, gills and $\mathrm{PAH}$ type metabolites) and EROD activity in gills, on the other hand, several correlations were established between EROD activity and heavy metals (Table 7). The majority of correlations were established between heavy metal concentrations in sediments and EROD where all correlations established were negative.

Inhibitory effects of different metals on the biotransformation of organic chemicals have been reported both in in vitro and in vivo models. Benedetti et al. (2007) observed in Trematomus bernacchii injected with B(a)P, a EROD induction suppressed by more than $80 \%$ in organisms co-exposed to cadmium and copper; while those treated with $\mathrm{BaP}$ and other metals $(\mathrm{Hg}, \mathrm{Ni}, \mathrm{Pb})$ showed an EROD activity comparable to organisms exposed only to BaP. In vivo studies on fish (Dicentrarchus labrax and Microgradus tomcod) have demonstrated significantly reduced EROD activity after exposure to PAHs combined with simultaneous or delayed administration of heavy metals (Oliveira et al., 2004; Sorrentino et al., 2005). According to Eggens et al. (1992), heavy metal contamination is a possible explanation for the discrepancies between the organic xenobiotic levels sometimes observed in fish tissue and its EROD activity. This explanation may be supported by other studies where low levels of EROD activity coincide with high content of heavy metals (Romeo et al., 1994).

Several mechanisms to explain cellular metal toxicity have been documented. Heavy metals can alter the activity of enzymes by binding to their functional groups (sulfhydryl, carboxyl, imidazol, etc.) or by displacing the metal associated with the enzyme (Viarengo, 1985).

Jönsson et al. (2006) observed $5 \mu \mathrm{M}$ copper inhibited PAH-induced EROD activity in bass gills and they suggested that the apical membrane of gills has a low permeability to copper, and hence protects the intracellular functions of the respiratory cells. This enables fish gills to retain the potential of first-pass metabolism of waterborne organic compounds while simultaneously being exposed to copper.

Table 7

Correlations $(\mathrm{p}<0.05)$ between PAH and heavy metal concentrations in tissues, sediments and water and EROD activity in gills and liver of S. senegalensis (G: correlation with EROD activity in gills; L: Correlation with EROD activity in liver.)

\begin{tabular}{llll}
\hline & Fraction & p value & r value \\
\hline Gills & & & \\
Arsenic & $\mathrm{a}$ & 0.010 & $0.410(\mathrm{G})$ \\
Copper & $\mathrm{a}$ & 0.000 & $0.427(\mathrm{G})$ \\
Liver & & & \\
Phenanthrene & Metabolite & 0.030 & $0.360(\mathrm{~L})$ \\
& & & \\
Sediment & & & \\
Arsenic & Oxidizable & 0.001 & $-0.867(\mathrm{G})$ \\
Lead & Reducible & 0.038 & $-0.661(\mathrm{G})$ \\
Lead & Oxidizable & 0.043 & $-0.648(\mathrm{G})$ \\
Cadmium & Interchangeable & 0.038 & $-0.661(\mathrm{G})$ \\
Copper & Interchangeable & 0.009 & $-0.770(\mathrm{G})$ \\
Copper & Reducible & 0.043 & $-0.648(\mathrm{G})$ \\
Iron & Reducible & 0.005 & $-0.806(\mathrm{G})$ \\
Zinc & Interchangeable & 0.003 & $-0.830(\mathrm{G})$ \\
Zinc & Reducible & 0.008 & $-0.782(\mathrm{G})$ \\
& & & \\
Water & & & \\
Cadmium & Labile organic dissolved & 0.029 & $0.685(\mathrm{G})$ \\
Cadmium & Particulate & 0.011 & $0.758(\mathrm{G})$ \\
Cadmium & Total & 0.011 & $0.758(\mathrm{G})$ \\
Cadmium & Dissolved & 0.048 & $0.636(\mathrm{G})$ \\
Copper & particulate & 0.036 & $0.686(\mathrm{G})$ \\
Copper & Labile organic & 0.030 & $0.682(\mathrm{~L})$ \\
\hline Totalconcentration & &
\end{tabular}

a Total concentrations of metals were analyzed only in gills.
Goksoyr et al. (1994) showed that EROD inhibition produced by $\mathrm{Fe}^{2+}$ could be explained by altering $\mathrm{SH}$ groups of transmembrane proteins and their lipidic environment caused by oxyradical production via the Fenton reaction followed by lipid peroxidation.

In contrast to $\mathrm{Fe}^{2+}$, other metals such as $\mathrm{Zn}^{2+}$ bind directly to thiols (Knowles and Benson, 1983). Thus, their primary mechanism of cellular toxicity is through direct binding to sulfhydryl groups in proteins and enzymes (Quig, 1998). Therefore, redox-inactive metal's toxicity may be due to its ability to combine with sulfhydryl thiol $(-\mathrm{SH})$ groups by forming disulfide bridges $(-\mathrm{S}-\mathrm{S}-$ ), resulting in protein conformational changes and thereby preventing their normal function.

Other of metal concentrations in sediment correlated with EROD activity in gills were lead and cadmium. Most studies report the in vivo effects of $\mathrm{Pb}^{2+}$ heavy metal. Goering (1993) suggested that the interactions of $\mathrm{Pb}^{2+}$ with proteins may represent a fundamental mechanism by which $\mathrm{Pb}^{2+}$ exerts its toxicity. This metal interacts with enzyme functional groups, and high-affinity metal-binding proteins, such as Pb-binding proteins and metallothioneins, which can mediate this $\mathrm{Pb}^{2+}$-enzyme interaction.

In contrast, in studies of Bouraoui et al. (2008) and Lemaire-Gony and Lemaire (1996), effects of $\mathrm{Cd}^{2+}$ on EROD activity could be linked to the effect of $\mathrm{Cd}^{2+}$ on membranes.

Apparently contradictory effects have been reported (i.e. inhibition, induction) for EROD activity in this work. Several factors may contribute to the differences found including the species studied, the properties of the enzymes present in the analyzed tissue, the type of study (field or laboratory), the experimental conditions (e.g. temperature, test medium), the time and intensity of the exposure and the chemical form of the test compound, among others.

When the activities of biotransformation enzymes are determined from fish caught in their natural environment, it is quite difficult to judge whether the activities are on basal or induced levels. Seasonal variations in temperature affect the final enzyme activities in fish (Solé et al., 2006).

In complex chemical mixtures, such as those found in the polluted sediments from Ria de Huelva, EROD activity is likely to be the net result of additive, synergistic or antagonistic chemical interactions. Although the precise nature of these interactions was beyond the scope of the present study, the prevalence of LPAHs, the correlations between them and the metabolites in liver and correlation between EROD activity and phenanthrene suggests that PAHs were probably mainly responsible for the observed increase in EROD activity.

Although the measurement of EROD induction in fish is most commonly used as an indicator of exposure to polycyclic halogenated hydrocarbons (PHHs) and PAHs, it also responds to other classes of chemicals, such as polychlorinated dibenzo-p-dioxins (PCDDs), dibenzofurans (PCDFs), polychlorinated biphenyls (PCBs), and pesticides (Whyte et al., 2000).

Another important issue to consider is the ability of heavy metals to affect CYP1A activity. It is well known that the inhibitory effects of heavy metals on EROD activity and PAHs exist in the environment in complex mixtures which may contain AhR agonists as well as AhR antagonists that may compound biomarker results. A recent review on PAH ecotoxicology in marine ecosystems, emphasizes that there is a need for increased research efforts to clarify biological effects of two and three ring PAHs and PAH mixtures (Hylland, 2006). Some studies show that there are both synergistic and antagonistic interactions between low and high molecular weight PAHs and other compounds.

\subsection{Liver CYP1A immunoreactivity}

CYP1A catalytic activity assay shows a greater range of response than the CYP1A immunoreactivity but immunological recognition of CYP1A protein is generally not affected by physical factors that can affect catalytic activity (Collier et al., 1995). 
Table 8

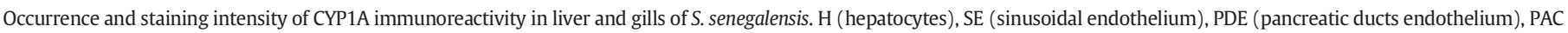
(pancreatic acinar cells), VSE (vascular system endothelium).

\begin{tabular}{|c|c|c|c|c|c|c|c|c|c|c|c|c|}
\hline \multirow{2}{*}{$\frac{\text { Cell type }}{\text { Liver (occ }}$} & \multicolumn{4}{|l|}{ Odiel } & \multicolumn{4}{|l|}{ Tinto } & \multicolumn{4}{|c|}{ Canal Padre Santo } \\
\hline & ence ${ }^{\mathrm{a}} /$ inten & \multirow[b]{2}{*}{ A '05 } & \multirow[b]{2}{*}{ O'05 } & \multirow[b]{2}{*}{ M '06 } & \multirow[b]{2}{*}{ O '04 } & \multirow[b]{2}{*}{ A '05 } & \multirow[b]{2}{*}{ O'05 } & \multirow[b]{2}{*}{ M '06 } & \multirow[b]{2}{*}{ O '04 } & \multirow[b]{2}{*}{ A '05 } & \multirow[b]{2}{*}{ O'05 } & \multirow[b]{2}{*}{$\bar{M}$ '06 } \\
\hline & O '04 & & & & & & & & & & & \\
\hline $\mathrm{H}$ & $-1-$ & $-1-$ & $+1+$ & $-1-$ & $\mathrm{a}$ & - & $++/+$ & $-1-$ & $-1-$ & $\mathrm{b}$ & $+1+$ & $\mathrm{b}$ \\
\hline $\begin{array}{l}H \\
\text { SE }\end{array}$ & $\begin{array}{l}-1- \\
-1-\end{array}$ & $\begin{array}{l}-1- \\
-1-\end{array}$ & $\begin{array}{l}+1+ \\
-1-\end{array}$ & $\begin{array}{l}-1- \\
-1-\end{array}$ & $\mathrm{a}$ & - & $\begin{array}{l}++1+ \\
-1-\end{array}$ & $\begin{array}{l}-1- \\
-1-\end{array}$ & $+1++1+++$ & $\mathrm{b}$ & $\begin{array}{l}+1+ \\
-1-\end{array}$ & $\mathrm{b}$ \\
\hline PDE & $+/+/++$ & $++/+++$ & $++/++1+++$ & $-1-$ & $\mathrm{a}$ & - & $+/+++$ & $-1-$ & $-1-$ & $\mathrm{b}$ & $+/++$ & $\mathrm{b}$ \\
\hline PAC & $+/+$ & $++/++$ & $+++/++$ & $+/+$ & $\mathrm{a}$ & $++/++$ & $+1+$ & $-1-$ & $+1+$ & $\mathrm{b}$ & $++/++$ & $\mathrm{b}$ \\
\hline VSE & $+/+/++$ & $+/+++$ & $+/+/++$ & $+/+$ & $\mathrm{a}$ & - & $+/++$ & $+/+$ & $+/++/+++$ & $\mathrm{b}$ & $+/++$ & $\mathrm{b}$ \\
\hline
\end{tabular}

a Occurrence in the relative frequency of stained cells: - (no staining seen), + (rare), ++ (multifocally), +++ (frequent)

b Intensity is the staining of the peroxidase stained immunoreactive cells: - (negative), $-/+$ (negative/mild) $,+($ mild $),+/++($ mild $/$ moderate $),++($ moderate $),++/+++($ moderate/ high), and +++ (high).

The induction response included an increase of staining intensity of a given cell type, and/or an increase in the number of CYP1A positive cell types within a tissue or organ (Table 8). No significant differences between sampling sites were observed with reference to frequency of S. senegalensis specimens with CYP1A-associated staining except in spring season in Tinto River with the lower frequency (Table 9). The occurrence in the relative frequency of stained cells (Table 8) was higher in autumn 2005 for all sampling sites corresponding with a higher quantity of heavy metals and higher EROD activity. Strong CYP1A occurrence was observed in acinar pancreatic cells, pancreatic duct epithelium and vascular system endothelium and negative/rare induction was observed in hepatocytes and sinusoidal endothelium (Fig. 3). Localization and sensitive induction of CYP1A in vascular endothelia have been reported for several teleost species as well (Schlezinger and Stegeman, 2000; Ortiz-Delgado et al., 2005). Endothelial cells are the first site of interaction with blood toxicants, and it has been suggested that they may be the primary target for the toxic action of CYP1Ainducing substances (Stegeman and Hahn, 1994). CYP1A-catalyzed metabolism of xenobiotics in the endothelium can have toxicological implications: neoplastic changes, altered pharmacokinetics of toxicants and altered availability to the underlying tissue or disruption of blood vessel functions (Schlezinger and Stegeman, 2000; Ortiz-Delgado et al., 2005).

The results obtained with CYP1A immunohistochemistry of the liver in the present study are in agreement with those reported by Husoy et al. (1996). Husoy et al. reported CYP1A induction in various tissues, including the liver, in flounder (Platichthys flesus) exposed to environmental contaminants by caging the fish in Sorfjorden, Norway. Myers et al. (1995) also found CYP1A induction in endothelial cells of arterioles associated with exocrine pancreas epithelial cells in English sole captured from a highly contaminated estuary of Puget Sound, WA, USA. Immunohistochemical determination of CYP1A induction in different cell types of fish may be important in determining whether and what types of neoplasm might develop as a result of exposure to chemical contaminants.

\subsection{Gill CYP1A immunoreactivity}

The induction response included different staining intensity of a given cell type and/or no significant differences in the number of CYP1A-positive cells in the gills between sampling sites (Table 10). Strongly positive CYP1A associated staining of the vascular system endothelia (Fig. 3A) and chloride cells (Fig. 3B) and a moderate staining of pillar cells (Fig. 3C) in gills was observed. Epithelial or mucous cells did not stain. No staining was evident in control fish.

In previous studies, induction of different cell types in gills have been reported after environmental exposure (Stegeman et al., 1991) and bioassays with PAHs (Mdegela et al., 2006) but there are few studies about the effects of metals over CYP1A induction in fish (Jönsson et al., 2006).

The strong staining in endothelial cells of the vasculature adds recent recognition that endothelium may be a common site of CYP1A induction in vertebrates from fish to mammals. The location of endothelial cells as an interface between blood-borne xenobiotics and underlying tissues can be important in toxicology. This could also involve altered metabolism of vasoactive factors, including nitric oxide and/or arachidonic acid (Husoy et al., 1994).

A moderate CYP1A staining was also observed in pillar cells. The major absorption site for waterborne chemicals is most likely the secondary lamellae, and therefore it seems probable that cells in the secondary lamellae obtained the highest exposure to pollutants (Jönsson et al., 2004). The extent of first-pass metabolism in these cells would consequently determine the exposure of the underlying cells as well as the systemic bioavailability of CYP1A-metabolized pollutants in fish.

Strongly positive CYP1A associated staining was also observed in primary filament cells. Due to the morphology and position in the primary lamella of these cells could be mucous or chloride cells, authors was agree with these cells were chloride cells, because histochemical techniques carried out with alcian blue and periodic acid Schiff (PAS) demonstrated that they are not mucous cells (unpublished data). In gills of rainbow trout exposed to waterborne copper (one of the most abundant metal in the Huelva estuary), metallothionein was induced

Table 9

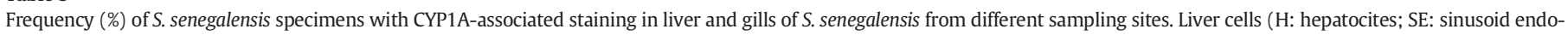

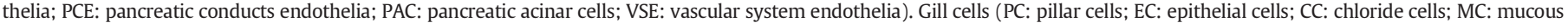
cells; VSE: vascular system endothelia). O: October; A: April; M: May.

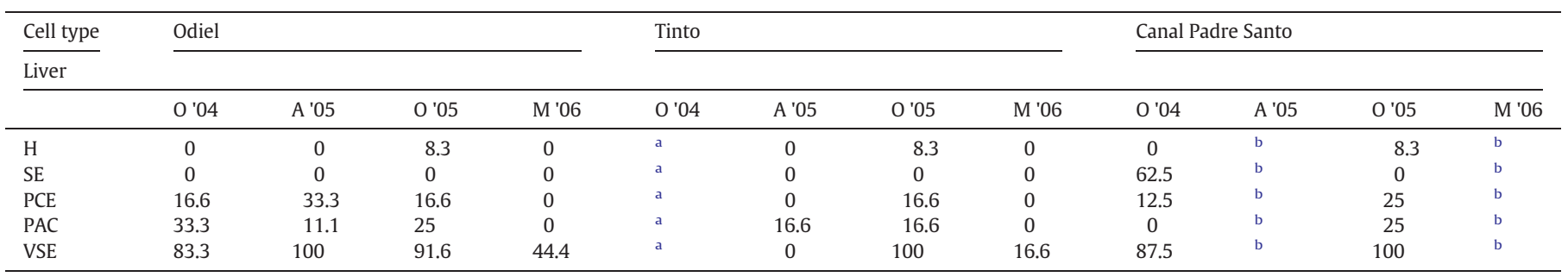

a An instrumental failure caused the damage of the samples.

b No S. senegalensis were captured in Canal Padre Santo during spring season. 

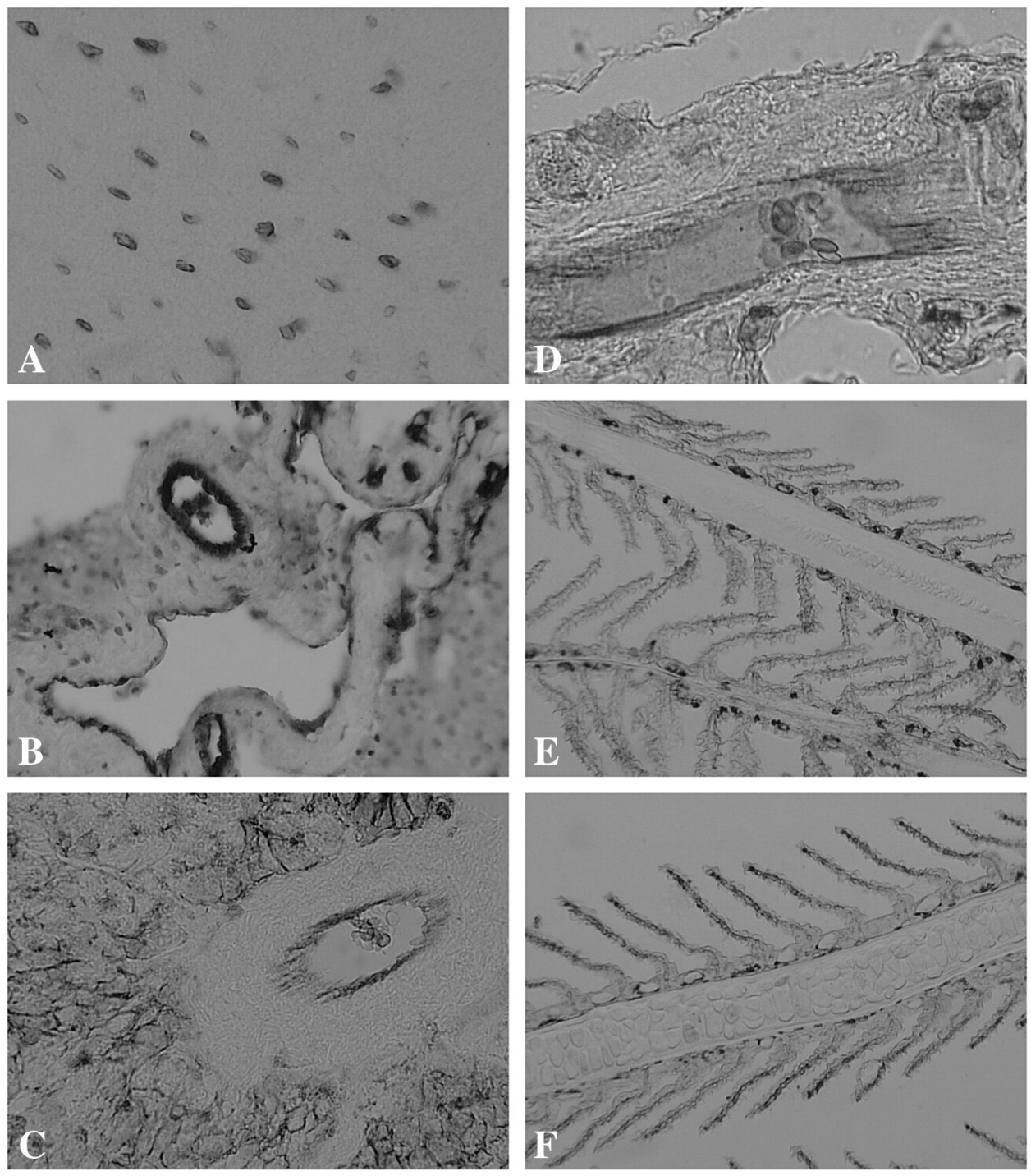

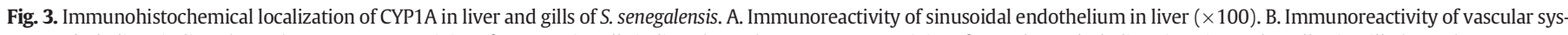

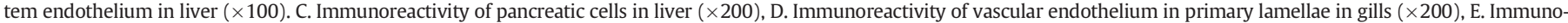
reactivity of chloride cells $(\times 200)$, F. Immunoreactivity of pillar cells in gills $(\times 400)$.

predominantly in chloride cells (Dang et al., 2000; Jönsson et al., 2006). This could reflect that the copper uptake is higher in chloride cells and therefore a high induction of CYP1A in these cells is probable.

In major sites a contradictory response was observed between EROD activity and immunoreactivity observed in different gill cells presumably due to specific action of other compounds different from heavy metals. Ortiz-Delgado et al. (2005) observed a similar response in gills of gilthead seabream exposed to benzo(a)pyrene. It would be necessary to quantify the immunostaining (i.e. using optic density or index) to find possible correlations between compounds and immunoreactivity of cells. Immunohistochemical localization may also call attention to specific cell types useful in environmental monitoring studies, as suggested by Stegeman et al. (1991). No significant differences between sampling sites were observed with reference to frequency of S. senegalensis

Table 10

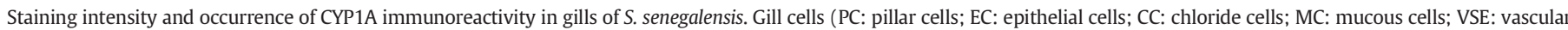
system endothelia). O: October; A: April; M: May.

\begin{tabular}{|c|c|c|c|c|c|c|c|c|c|c|c|c|}
\hline \multirow{2}{*}{$\frac{\text { Cell type }}{\text { Gills (occu }}$} & \multicolumn{4}{|l|}{ Odiel } & \multicolumn{4}{|l|}{ Tinto } & \multicolumn{4}{|l|}{ Canal Padre Santo } \\
\hline & \multirow{2}{*}{$\frac{\text { rrence }^{\mathrm{a}} / \text { int }}{\mathrm{O}^{\prime} 04}$} & \multirow{2}{*}{$\frac{\left.\text { sity }^{\text {b }}\right)}{\text { A '05 }^{\prime}}$} & \multirow[b]{2}{*}{ O '05 } & \multirow[b]{2}{*}{ M '06 } & \multirow[b]{2}{*}{ O '04 } & \multirow[b]{2}{*}{ A '05 } & \multirow[b]{2}{*}{ O '05 } & \multirow[b]{2}{*}{ M '06 } & \multirow[b]{2}{*}{ O '04 } & \multirow[b]{2}{*}{ A '05 } & \multirow[b]{2}{*}{ O '05 } & \multirow[b]{2}{*}{ M '06 } \\
\hline & & & & & & & & & & & & \\
\hline PC & $+1+$ & $+/+$ & $+/+1++$ & $-1-$ & $++/+/++$ & $+/+$ & $-1-$ & $-1-$ & $+/+^{a}$ & $\mathrm{~b}$ & $++/+/++$ & $\mathrm{b}$ \\
\hline EC & $-1-$ & $-1-$ & $-1-$ & $-1-$ & $-1-$ & $-1-$ & $-1-$ & $-1-$ & $-1-$ & $\mathrm{b}$ & $-1-$ & b \\
\hline $\mathrm{CC}$ & $+/++$ & $++/++/+++$ & $++/++$ & $+/+$ & $+/++$ & $++/++$ & $++/+++$ & $+/+$ & $++1++1+++$ & $\mathrm{b}$ & $++/++$ & $\mathrm{b}$ \\
\hline MC & $-1-$ & $-1-$ & $-1-$ & $-1-$ & $-1-$ & $-1-$ & $-1-$ & $-1-$ & $-1-$ & $\mathrm{b}$ & $-1-$ & b \\
\hline VSE & $++/++$ & $++/++/+++$ & $++/++$ & $+/+$ & $++/++/+++$ & $++/++/+++$ & $+/++$ & $+/+$ & $++/++$ & b & $+/++$ & b \\
\hline
\end{tabular}

a Occurrence is the relative frequency of stained cells: - (no staining seen $),+$ (rare), ++ (multifocally), +++ (frequent).

b Intensity is the staining of the peroxidase stained immunoreactive cells: - (negative), $-/+$ (negative/mild), $+($ mild $),+/++$ (mild/moderate), $++($ moderate), $++/+++($ moderate/ high), and +++ (high). 
Table 11

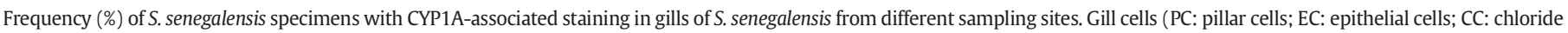
cells; MC: mucous cells; VSE: vascular system endothelia). O: October; A: April; M: May.

\begin{tabular}{|c|c|c|c|c|c|c|c|c|c|c|c|c|}
\hline$\frac{\text { Cell type }}{\text { Gills }}$ & \multicolumn{4}{|l|}{ Odiel } & \multicolumn{4}{|l|}{ Tinto } & \multicolumn{4}{|c|}{ Canal Padre Santo } \\
\hline & O '04 & A '05 & O '05 & M '06 & O '04 & A '05 & O '05 & M '06 & O '04 & A '05 & O '05 & M '06 \\
\hline PC & 25 & 33.3 & 33.3 & 0 & 75 & 16.6 & 0 & 0 & 62.5 & $\mathrm{~b}$ & 33.3 & $\mathrm{~b}$ \\
\hline EC & 0 & 0 & 0 & 0 & 0 & 0 & 0 & 0 & 0 & b & 0 & $\mathrm{~b}$ \\
\hline $\mathrm{CC}$ & 100 & 100 & 100 & 80 & 100 & 50 & 100 & 8.3 & 100 & b & 100 & $\mathrm{~b}$ \\
\hline MC & 0 & 0 & 0 & 0 & 0 & 0 & 0 & 0 & 0 & b & 0 & $\mathrm{~b}$ \\
\hline VSE & 100 & 100 & 75 & 90 & 100 & 33.3 & 100 & 8.3 & 100 & $\mathrm{~b}$ & 100 & $\mathrm{~b}$ \\
\hline
\end{tabular}

a An instrumental failure caused the damage of the samples.

b No S. senegalensis were captured in Canal Padre Santo during spring season.

specimens with CYP1A-associated staining except in the spring season in Tinto River with the lower frequency (Table 11).

\section{Conclusions}

The results substantiated the utility of CYP1A measurement as a biomarker for use by aquatic toxicologists.

Results indicated that catalytic assays appear to be more sensitive than the immunochemical assay at its current stage of development, but the use of both methods is recommended for monitoring programs.

The liver showed a relation between EROD activity and LAPHs liver metabolites so we can consider FACs such as sensible biomarkers. There was a relation between EROD activity and CYP1A induction in 2005 autumn when metal concentrations were highest although the correlation existed only with the copper concentration in water.

This study indicates that gills are a sensitive organ in the pollutant effect studies indicating important biochemical effects of heavy metals on gill EROD and suggesting that exposure to heavy metal ions may cause complex changes in the cytochrome P450-dependent metabolism in fish.

A decrease of EROD activity in gills of S. senegalensis have been well related with heavy metal concentrations in sediments of Huelva estuary demonstrating EROD activity is a robust biomarker not only PAH but also heavy metal pollution. On the other hand, it is observed a contradictory response between EROD activity and immunoreactivity of gill cells.

In the environment, interactions of cytochrome P450-inducing and cytochrome P450-inhibiting components (such as heavy metals) can be expected and must be taken into consideration. This study supports the idea that tissue-specific patterns of CYP1A expression could contribute to our understanding of exposure mechanisms in wild populations of fish. However, development of an understanding of the numerous factors influencing the uptake and effects of toxicants in complex ecosystems is an extremely difficult process.

\section{Acknowledgments}

This work has been supported by Project SEAPAT: "Biomarkers and histopathology in gilthead seabream, Sparus aurata, and Senegal sole, Solea senegalensis" (CICYT, REN 2003-09361-CO3-03).

\section{References}

Aas, E., Baussant, T., Balk, L., Liewenborg, B., Anderse, O.K., 2000. PAH metabolites in bile cytochrome P4501A and DNA adducts as environmental risk parameters for chronic oil exposure: a laboratory experiment with Atlantic cod. Aquat. Toxicol. 51, 241-258.

Almroth, B.C., Sturve, J., Stephensen, E., Holth, T.F., Forlin, L., 2008. Protein carbonyls and antioxidant defenses in corkwing wrasse (Symphodus melops) from a heavy metal polluted and a PAH polluted site. Mar. Environ. Res. 66, 271-277.

Arinc, E., Sen, A., 1999. Hepatic cytochrome P4501A and 7-ethoxyresorufin O-deethylase induction in mullet and common sole as an indicator of toxic organic pollution in Izmir Bay, Turkey. Mar. Environ. Res. 48, 147-160.

Benedetti, M., Martuccio, G.,Fattorini, D.,Canapa, A.,Barucca, M.,Nigro, M., Regoli, F., 2007. Oxidative and modulatory effects of trace metals on metabolism of polycyclic aromatic hydrocarbons in the Antarctic fish (Trematomus bernacchii). Aquat. Toxicol. 85 (3), 167-175.

Bols, N.C.,Schirmer, K.,Joyce, E.M.,Dixon, D.G.,Greenberg, B.M.,Whyte, J.J., 1999. Ability of polycyclic aromatic hydrocarbons to induce 7-ethoxyresorufin-0-deethylase activity in a trout liver cell line. Ecotoxicol. Environ. Saf. 44, 118-128.

Bouraoui, Z., Banni, M., Ghedira, J., Clerandeau, C., Guerbej, H., Narbonne, J.F., Boussetta, H., 2008. Acute effects of cadmium on liver phase I and phase II enzymes and metallothionein accumulation on sea bream Sparus aurata. Fish Physiol. Biochem. 34, 201-207.

Bucheli, T.D.,Fent, K., 1995. Induction of cytochrome P450 as a biomarker for environmental contamination in aquatic ecosystems. Crit. Rev. Environ. Sci. Technol. 25, 201-268.

Burke, M.D., Mayer, R.T., 1974. Ethoxyresorufin: direct fluorimetric assay of microsomal$O$-deethylation which is preferentially inducible by 3-methylcholanthrene. Drug Metab. Dispos. 2, 583-588.

Cheung K.C.,Leung, H.M. Kong K.Y. Wong M.H, 2007. Residual levels of DDTs and PAHs in freshwater and marine fish from Hong Kong markets and their health risk assessment. Chemosphere 66 (3), 460-468.

Collier, T.K., Anulacion, B.F., Stein, J.E., Goksoyr, A., Varanasi, U., 1995. A field evaluation of cytochrome P4501A as a biomarker of contaminant exposure in three species of flatfish. Environ. Toxicol. Chem. 14 (1), 143-152.

Costa, P.M.,Diniz, M.S.,Caeiro, S.,Lobo, J.,Martins, M.,Ferreira, A.M.,Caetano, M.,Vale, C., Del Valls, T.A., Costa, M.H., 2009. Histological biomarkers in liver and gills of juvenile (Solea senegalensis) exposed to contaminated estuarine sediments: a weighted indices approach. Aquat. Toxicol. 92 (3), 202-212.

Costa, J., Ferreira, M., Rey-Salgueiro, L., Reis-Henriques, M.A., 2011. Comparison of the waterborne and dietary routes of exposure on the effects of benzo(a)pyrene on biotransformation pathways in Nile tilapia (Oreochromis niloticus). Chemosphere 84 (10), 1452-1460.

Cvec, G., 1990. Membrane electrostatics. Biochem. Biophys. Acta 1031, 311-382.

Dang, Z.C.,Flik, G.,Ducouret, B.,Hogstrand, C.,Wendelaar, B.S.E.,Lock, R.A.C., 2000. Effects of copper on cortisol receptor and metallothionein expression in gills of Oncorhynchus mykiss. Aquat. Toxicol. 51, 45-54.

Davidson, M.C.,Lorna, E.W.,Ure, A.M., 1999. Effect of sample preparation on the operational speciation of cadmium and lead in freshwater sediment. Fresenius J. Anal. Chem. 363, 134-136.

Desantis, S Corriero, A Cirillo, F. Deflorio, F Brill, R Griffiths, M Lobata, A L De la Serna, J.M., Bridges, C.R., Kime, D.E., De Metrio, G., 2005. Immunohistochemical localization of CYP1A, vitellogenin and zona radiata proteins in the liver of swordfish (Xiphias gladius L.) taken from the Mediterranean Sea, South Atlantic, South Western Indian and Central North Pacific Oceans. Aquat. Toxicol. 71, 1-12.

Dinis, M.T., 1992. Aspects of the potential of Solea senegalensis Kaup for aquaculture: larval rearing and weaning to an artificial diet. Aquac. Fish Manag. 23, 515-520.

Drake, P., Arias, A.M., Rodríguez, A., 1984. Cultivo extensivo de peces marinos en los esteros de las salinas de San Fernando (Cádiz): II. Características de la producción de peces. Technical Report 116. Fisheries Research Institute, Spain, pp. 1-23.

Eggens, M., Galgani, F., Klungsøyr, J., Everts, J., 1992. Hepatic EROD activity in dab Limanda limanda in the German Bight using an improved plate-reader method. Mar. Ecol. Prog. Ser. 91, 71-75.

Gaetke, L.M.,Chow, C.K., 2003. Copper toxicity, oxidative stress, and antioxidant nutrients. Toxicology 189, 147-163.

Gagnon, M.M., Holdway, D.A., 2000. EROD induction and biliary metabolite excretion following exposure to the water accommodated fraction of crude oil and to chemically dispersed crude oil. Arch. Environ. Contam. Toxicol. 38 (1), 7.

Galván, L., Olías, M.,Cerón, J.C., Cánovas, C.R.,Pérez-López, R., Nieto, J.M., 2013. Assessment of the dissolved pollutant flux of the Odiel River (SW Spain) during a wet period. Sci. Total Environ. 463-464, 572-580.

Goering, P.L., 1993. Lead-protein interactions as a basis for lead toxicity. Neurotoxicology $14(2-3), 45-60$.

Goksoyr, A., Bjornevik, M., Maage, A., 1994. Effects of dietary iron concentrations on the cytochrome P450 system of Atlantic salmon (Salmo salar). Can. J. Fish. Aquat. Sci. 51, 315-319.

Henczova, M., Deer, A.K., Filla, A., Konlósi, V., Mink, J., 2008. Effects of $\mathrm{Cu}^{2+}$ and $\mathrm{Pb}^{2+}$ on different fish species: liver cytochrome P450-dependent monooxygenase activities and FTIR spectra. Comp. Biochem. Physiol. C 148, 53-60. 
Husoy, A.M.,Myers, M.S.,Willis, M.L.,Collier, T.K..Celander, M.,Goksoyr, A., 1994. Immunohistochemical localization of CYP1A and CYP3A-like isozymes in hepatic and extrahepatic tissues of Atlantic cod (Gadus morhua L.), a marine fish. Toxicol. Appl. Pharmacol. 129, 294-308.

Husoy, A.M., Myers, M.S., Goksoyr, A., 1996. Cellular localization of cytochrome P450 (CYP1A) induction and histology in Atlantic cod (Gadus morhua L.) and European flounder (Platichthys flesus) after environmental exposure to contaminants by caging in Sonfjorden Norway. Aquat. Toxicol. 36, 53-74.

Hylland, K., 2006. Polycyclic aromatic hydrocarbons (PAH). Ecotoxicology in marine ecosystems. J. Toxicol. Environ. Health A 69, 109-123.

Jimenez-Tenorio, N.,Salamanca, M.J.,Garcia-Luque, E.,Gonzalez de Canales, M.L., Del Valls, T.A., 2008. Chronic bioassay in benthic fish for the assessment of the quality of sediments in different areas of the coast of Spain impacted by acute and chronic oil spills. Environ. Toxicol. 23 (5), 634-642.

Jönsson, M.E., Brunström, B.,Ingebrigtsen, K., Brandt, I., 2004. Cell-specific CYP1A expression and benzo(a)pyrene adduct formation in gills of rainbow trout (Oncorhynchus mykiss) following CYP1A induction in the laboratory and in the field. Environ. Toxicol. Chem. 23 (4), 874-882

Jönsson, M.E.,Carlssson, C., Smith, R.W.,Pärt, P., 2006. Effects of copper on CYP1A activity and epithelial barrier properties in the rainbow trout gill. Aquat. Toxicol. 79, 78-86.

Kamer, T.T., 1994. Dutch standards for contaminated sediments. Evaluatienota Water 21 (250), 27-28.

Kaup, J.J., 1858. Übersicht der Soleinae, der vierten Subfamilie der Pleuronectidae. Arch. Naturgesch. 24 (1), 94-104.

Kloepper-Sams, P.J., Benton, E., 1994. Exposure of fish to biologically treated bleached-kraft effluent. 2. Induction of hepatic cytochrome P4501A in mountain whitefish (Prosopium williamsoni) and other species. Environ. Toxicol. Chem. 13 (9), 1483-1486.

Knowles, F.C., Benson, A.A., 1983. The biochemistry of arsenic. Trends Biochem. Sci. 8, $178-180$.

Korashy, H.M., El-Kadi, A.O.S., 2008. Modulation of TCDD-mediated induction of cytochrome P450 1A1 by mercury, lead, and copper in human HepG2 cell line. Toxicol. in Vitro 22, 154-158.

Lemaire-Gony, S., Lemaire, P., 1996. Interactive effects of cadmium and BaP on cellular structure and biotransformation enzymes of the liver of the European eel (Anguilla Anguilla). Aquat. Toxicol. 22, 145-160.

Levengood, J., Schaeffer, D., 2011. Polycyclic aromatic hydrocarbons in fish and crayfish from the Calumet region of southwestern Lake Michigan. Ecotoxicology 20 (6), 1411-1421.

Lima, D.,Santos, M.M.,Ferreira, A.M.,Micaelo, C., Reis-Henriques, M.A., 2008. The use of the shanny (Lipophrys pholis) for pollution monitoring: a new sentinel species for the northwestern European marine ecosystems. Environ. Int. 34, 94-101.

Lu, G.H.,Ji, Y.,Zhang, H.Z., Wu, H., Qin, J., Wang, C., 2010. Active biomonitoring of complex pollution in Taihu Lake with Carassius auratus. Chemosphere 79, 588-594.

Martin Jr., D.W., Mayes, P.A., Rodwell, V.W., Granner, D.K., 1985. Harper's Review of Biochemistry, 20th ed. Lange Medical Publications, Los Altos, CA, p. 132.

Mdegela, R.,Myburgh, J.,Correia, D.,Braathen, M.,Ejobi, F.,Botha, C.,Sandvik, M.,Skaare, J.U. 2006. Evaluation of the gill filament-based EROD assay in African sharptooth catfish (Clarias gariepinus) as a monitoring tool for waterborne PAH-type contaminants. Ecotoxicology 15, 51-59.

Mondon, J.A., Duda, S., Nowak, B.F., 2001. Histological, growth and 7-ethoxyresorufin $O$-deethylase (EROD) activity responses of greenback flounder (Rhombosolea tapirina) to contaminated marine sediment and diet. Aquat. Toxicol. 54, 231-247.

Myers, M.S.,Willis, M.L.,Husoy, A.M.,Goksoyr, A.,Collier, T.K., 1995. Immunohistochemica localization of cytochrome P4501A in multiple types of contaminant-associated hepatic lesions in English sole (Pleuronectes vetulus). Mar. Environ. Res. 39, 283-288.

Nahrgang, J., Jönsson, M., Camus, L., 2010. EROD activity in liver and gills of polar cod (Boreogadus saida) exposed to waterborne and dietary crude oil. Mar. Environ. Res. 70, 120-123.

Narbonne, J.F., Djomo, J.E., Ribera, D., Ferrier, V., Garrigues, P., 1999. Accumulation kinetics of polycyclic aromatic hydrocarbons adsorbed to sediment by the mollusk (Corbicula fluminea). Ecotoxicol. Environ. Saf. 42, 1-8.

Nogueira, L., Rodrigues, A.C.,Trídico, C.P.,Fossa, C.E.,de Almeida, E.A., 2011. Oxidative stress in Nile tilapia (Oreochromis niloticus) and armored catfish (Pterygoplichthys anisitsi) exposed to diesel oil. Environ. Monit. Assess. 180 (1-4), 243-255.

Oliva, M., Garrido, M.C., Sales Márquez, D., González de Canales, M.L., 2009. Sublethal and lethal toxicity in juvenile Senegal sole (Solea senegalensis) exposed to copper: a preliminary toxicity range-finding test. Exp. Toxicol. Pathol. 61 (2), 113-121.

Oliveira, M.,Santos, M.A.,Pacheco, M., 2004. Glutathione protects heavy metal-induced inhibition of hepatic microsomal ethoxyresorufin O-deethylase activity in Dicentrarchus labrax L. Ecotoxicol. Environ. Saf. 58, 379-385.

Oliveria, M., Pacheco, M.,Santos, M.A., 2007. Cytochrome P4501A, genotoxic and stress responses in golden grey mullet (Liza aurata) following short term exposure to phenanthrene. Chemosphere 66, 1284-1291.

Ortiz-Delgado, J.B., Segner, H., Sarasquete, C., 2005. Cellular distribution and induction of CYP1A following exposure of gilthead seabream (Sparus aurata) to waterborne and dietary benzo(a)pyrene and 2,3,7,8-tetrachlorodibenzo-p-dioxin: an immunohistochemical approach. Aquat. Toxicol. 75, 144-161.

Ortiz-Delgado, J.B.,Segner, H.,Arellano, J.M.,Sarasquete, C., 2007. Histopathological alterations, EROD activity, CYP1A protein and biliary metabolites in gilthead seabream (Sparus aurata) exposed to benzo(a)pyrene. Histol. Histopathol. 22, 417-432.

Ortiz-Delgado, J.B., Beherens, A., Segner, H., Sarasquete, C., 2008. Tissue-specific induction of EROD activity and CYP1A protein in (Sparus aurata) exposed to $\mathrm{B}(a) \mathrm{P}$ and TCDD. Ecotoxicol. Environ. Saf. 69 (1), 80-88.
Pathiratne, A.,Chandrasekera, L.W.H.U.,Pathiratne, K.A.S., 2008. Use of biomarkers in Nile tilapia (Oreochromis niloticus) to assess the impacts of pollution in Bolgoda Lake, an urban water body in Sri Lanka. Environ. Monit. Assess. 156 (1-4), 361-375.

Pérez-López, R., Nieto, J.M., López-Cascajosa, M.J., Díaz-Blanco, M.J., Sarmiento, A.M., Oliveira, V.,Sánchez-Rodas, D., 2011. Evaluation of heavy metals and arsenic speciation discharged by the industrial activity on the Tinto-Odiel estuary, SW Spain. Mar. Pollut. Bull. 62, 405-411.

Quig, D., 1998. Cysteine metabolism and metal toxicity. Altern. Med. Rev. 3, 262-270.

Romeo, M., Mathieu, A., Gnassia-Barelli, M., Romana, A., Lafaurie, M., 1994. Heavy metal content and biotransformation enzymes in two fish species from the NW Mediterranean. Mar. Ecol. Prog. Ser. 107, 15-22.

Roy, L.A., Steinert, S., Bay, S.B., Greenstein, D., Sapozhnikova, Y., Bawardi, O., Leifer, I. Schlenk, D., 2003. Biochemical effects of petroleum exposure in hornyhead turbot (Pleuronichthys verticalis) exposed to a gradient of sediments collected from a natural petroleum seep in CA, USA. Aquat. Toxicol. 65, 159-169.

Ruiz Cánovas, C., Olias, M., Vazquez-Suñé, E., Ayora, C., Nieto, J.M., 2012. Influence of releases from a fresh water reservoir on the hydrochemistry of the Tinto River (SW Spain). Sci. Total Environ. 416, 418-428.

Sainz, A., Grande, J.A., De la Torre, M.L., 2005. Application of a systemic approach to the study of pollution of the Tinto and Odiel rivers (Spain). Environ. Monit. Assess. 102 435-445.

Salazar-Coria, L., Amezcua-Allieri, M.A., Tenorio-Torres, M., González-Macías, C., 2007. Polyaromatic hydrocarbons (PAHs) and metal evaluation after a diesel spill in Oaxaca, Mexico. Bull. Environ. Contam. Toxicol. 79, 462-467.

Sanchez, W., Palluel, O., Meunier, L., Coquery, M., Porcher, J.M., Sélim, A.A., 2005. Copperinduced oxidative stress in three-spined stickleback: relationship with hepatic metal levels. Environ. Toxicol. Pharmacol. 19, 177-183.

Schlezinger, J.J.,Stegeman, J.J., 2000. Induction of cytochrome P4501A in the American ee by model halogenated and non-halogenated aryl hydrocarbon receptor agonists. Aquat. Toxicol. 50, 375-386.

Shailaja, M.S.,D'Silva, C., 2003. Evaluation of impact of PAH on a tropical fish (Oreochromis mossambicus) using multiple biomarkers. Chemosphere 53, 835-841.

Solé, M., Kopecka, J., García de la Parra, L.M., 2006. Seasonal variations of selected biomarkers in sand gobies (Pomatoschistus minutus) from the Guadalquivir Estuary, southwest Spain. Arch. Environ. Contam. Toxicol. 50, 249-255.

Sorrentino, C., Roy, N.K.,Courtenay, S.C.,Wirgin, I., 2005. Co-exposure to metals modulates CYP1A mRNA inducibility in Atlantic tomcod (Microgadus tomcod) from two populations. Aquat. Toxicol. 75, 238-252.

Spies, R.B., Davis, P.H.,Stuerner, D.H., 1980. Ecology of a petroleum seep off the California Coast. In: Geyer, R. (Ed.), Marine Environmental Pollution. Elsevier, Amsterdam, pp. 229-263.

Stegeman, J.J.,Hahn, M.E., 1994. Biochemistry and molecular biology of monooxygenases: current perspectives on forms, functions, and regulation of cytochrome P450 in aquatic species. In: Malins, D.C., Ostrander, G.K. (Eds.), Aquatic Publishers, Boca Raton, pp. 87-203.

Stegeman, J.J., Smolowitz, R.M., Hahn, M.E., 1991. Immunohistochemical localization of environmentally induced cytochrome P4501A1 in multiple organs of the marine teleost (Stenotomus chrysops, Scup). Toxicol. Appl. Pharmacol. 110, 486-504.

Toccane, J.F., Teissie, J., 1990. Ionization of phospholipids and phospholipid-supported interfacial lateral diffusion of protons in membrane model systems. Biochim. Biophys. Acta 1031, 111-142.

USEPA, 1996. United States Environmental Protection Agency. Method 3540C: soxhlet extraction. www.epa.gov.

USEPA, 2000. United States Environmental Protection Agency. Method 3620C: florisil cleanup. www.epa.gov.

Vakharia, D.D., Liu, N., Pause, R., Fasco, M., Bessette, E., Zhang, Q.Y., Kaminsky, L.S., 2001. Polycyclic aromatic hydrocarbons/metal mixtures: effect on PAH induction of CYP1A1 in human HEPG2 cells. Drug Metab. Dispos. 29, 999.

Van der Weiden, M.E., Hanegraaf, F.H.M., Eggens, M.L., Celander, M., Seinen, W., Van den Berg, M., 1994. Temporal induction of cytochrome P4501A in the mirror carp (Cyprinus carpio) after administration of several polycyclic aromatic hydrocarbons. Environ. Toxicol. Chem. 13, 797-802.

Van der Oost, R.,Beyer, J.,Vermeulen, N.P.E., 2003. Fish bioaccumulation and biomarkers in environmental risk assessment: a review. Environ. Toxicol. Phar. 13, 57-149.

Viarengo, A., 1985. Biochemical effects of trace metals. Mar. Pollut. Bull. 16, 153-158.

Vicente Martorell, J.J., Galindo-Riaño, M.D., García-Vargas, M., Castro-Granado, D., 2009. Bioavailability of heavy metals monitoring water, sediments and fish species from polluted estuary. J. Hazard. Mater. 162, 823-836.

Vicente-Martorell, J.J., Galindo-Riaño, M.D., Carcia-Vargas, M., Granado-Castro, M.D., 2008 Heavy metal speciation of estuarine sediments affected by acid mine drenage in the tinto and Odiel Estuary. Spain. Relationship to bioconcentration of fish tissues. Fresen. Environ. Bull. 17 (10b), 1744-1754.

Vieira, L.R., Gravato, C., Soares, A.M.V.M., Morgado, F., Guilhermino, L., 2009. Acute effects of copper and mercury on the estuarine fish (Pomatoschistus microps): linking biomarkers to behaviour. Chemosphere 76, 1416-1427.

Whyte, J.J., Karrow, N.A., Boermans, H.J.,Dixon, D.G., Bols, N.C., 2000. Combined methodologies for measuring exposure of rainbow trout (Oncorrynchus mykiss) to polycyclic aromatic hydrocarbons (PAHs) in creosote contaminated microcosms. Polycycl. Aromat. Compd. 18, 71-98. 